\title{
PHILOSOPHICAL ASPECTS OF HEALTH
}

\section{Emanuel Orban,}

College of Business and Hotel Management in Brno (Bohemia), Statistical Office of the Slovak Republic in Bratislava

emoorbo@gmail.com

ORCID 0000-0003-2951-4227

DOI: https://doi.org/10.34017/1313-9703-2021-1(17)-2(18)-61-64

\section{Анотация}

Емануел Орбан. Философските аспекти на здравето. Здравословният начин на живот е предизвикателство на постмодерното общество, чиито корени се връщат в дълбока древност, когато вече документираме съществуването на SPA терапии, свързани с човешкото тяло. По всяко време значението на здравето е пряко свързано с психологическите функции, за които говореха гръцките философи, подчертавайки ролята на позитивното мислене и бистрия ум. Основата на успеха е ранната профилактика на нежелани заболявания, която, до известна степен, включва правилното хранене, физическите упражнения и хигиенните навици. Здравето е важна ценност, която влияе върху качеството на човешкия живот.

Ключови думи: философия на здравето, начин на живот, медицина, ценност

\section{Резюме}

Емануель Орбан. Філософські аспекти здоров'я. Здоровий спосіб життя - це виклик постмодерного суспільства, коріння якого сягає глибокої давнини, коли ми вже фіксуємо існування спа-терапевтичної терапії, пов'язаної з людським тілом. В даний час важливість здоров'я безпосередньо пов'язана з психологічними функціями, які, до речі, заявили грецькі філософи, роблячи безпосередній акцент на позитивному мисленні та чистому розумі. Основою успіху є рання профілактика небажаних захворювань, до якої, певною мірою, стосуються також правильні харчові, фізичні вправи та гігієнічні звички. Здоров'я є важливою цінністю, яка впливає на якість життя людини.

Ключові слова: філософія здоров'я, спосіб життя, медицина, цінність

\begin{abstract}
Emanuel Orban. Philosophical Aspects of Health. A healthy lifestyle is a challenge of postmodern society, whose roots go back to antiquity, when we already record the existence of spa medical therapeutic procedures related to the human body. At present, the importance of health is directly linked to psychological functions, which, incidentally, have been declared by Greek philosophers who placed an immediate emphasis on positive thinking and pure reason. The basis of success is early prevention of unwanted diseases, which involves, to a certain extent, proper eating, exercise and hygiene practices. Health is an important value that affects the quality of human life.

Key words: philosophy of health, lifestyle, medicine, value

Introduction to the philosophy of health. Health is the most valuable asset, and by the way it is one of the highest values of human earthly life, as it is an important starting point for a happy and contented life (Děd, 2016). It represents the primary life ambition of the human individual, subject to variability depending on factors (climate changes, urban versus rural environment, physiological phenomena - reactions of the organism), which has been placed on a pedestal by various cultural
\end{abstract}


communities dedicated to the transformation of evil into good and the ugly into beautiful. One of the key theses of the philosophy of syncriticism is a maxim of human existence, which is a culture that emphasizes the transformation of evil into good and the ugly into beautiful (Piaček, 2002) The issue of health and lifestyle was also given special attention by important classical philosophers in their key works (references to Empedocles, Aristotle, Epicurus, etc.) According to a Greek philosopher from the Hellenistic period, Epicurus of Samus, philosophy contributes to the health of the human soul (Farkašová, 2004) The ancient Greek philosopher and founder of logic Aristotle regards a healthy lifestyle to be a matter of wisdom and reason. Aristotle considered the state of bliss, harmonic perfection - the principle of eudaimonia, to be the meaning of human actions. (Rybár, 2010) The ancient Greek philosopher Empedocles, an eclectic, was considered a healer of diseases on the public stage. He mastered magical practices perfectly, he considered primordial elements - fire, water, air and earth to be root elements (Zaviš, 2012) In their efforts, these personalities constantly pointed to the cult of the body, specifically to the achievement of the balance of beauty of body and spirit, which is directly connected with ancient cultures of Egypt and Greece. The mentioned cultures knew the healing effects of sea water, they also managed to cope with chronic skin diseases and common injuries. They were also able to apply various healing procedures related to mud wraps, iodine tinctures and mineral treatments to the surface of the human body.

Comprehensive spa treatment contributes to the regeneration of not only physical but also mental strength, ie. it induces positive thinking in the human individual. The psycho-hygienic function, which also characterizes most current wellness stays, is in the forefront of spa treatment. The spa industry had and still has a ritual significance, because it is associated with a cleansing and regenerative function in the form of revitalization of individual vital functions, especially the musculoskeletal system. "Ancient Greece, Rome and Egypt can be described as the cradle of use of use of water sources. Water was also worshipped in various religions, and purification of the body became an important ritual because they believed that thermal and mineral springs were gifts from the gods. " (Mrkvová, 2016, p. 20) Spa procedures are diverse in terms of indication focus, usually it is the application of following ingredients to the body surface, e.g. peat, mud, etc.

Health is a biological phenomenon that reflects the physical and mental state of man, the concept of which is subject to variability from a historical, cultural and religious point of view. The health status of a human individual also depends on his stay at a certain time and space. Health as an indicator of quality of life has a philosophical-anthropological dimension determining the emergence of medicine as a medical art. The human individual identifies it on the basis of knowledge, it contains an element based on gnoseology, on the basis of which it arrives at a factual statement regarding the determination of the diagnosis in cooperation with a doctor. Of course, a person's health depends on the following factors that can (lifestyle) cannot (age, genetic history) be influenced. The basis of the prevention of diseases of respiratory and civilizational nature is early prevention (regular medical examinations, early diagnosis, the option of immediate treatment, the administration of proper treatment). Acceptance of the treatment prescribed by the doctor from the patient's point of view is extremely important, as it contributes to the actual effectiveness of disease treatment. The philosophy of a healthy lifestyle is related to creating a feeling of joy in a given environment, in this case we can also talk about the healing therapy of positive thinking, which involves sending signals to the outside world. The following fact is also confirmed by the media-promoted slogans: "Live healthy"; "Healthy body, healthy spirit"; "Do something for your health"; etc. "The natural beauty and harmony of man corresponds to the ideal of modern calocagathy. Therefore, a person's physical activities focused on his active health and creative lifestyle have a trend towards the natural. Today, when it comes to for example, aerobics, fitness and wellness, their naturalness is emphasized in relation to the physical, moral and spiritual aspects of an individual. "(Oborný, 2015, p.100) The wellness category represents an effective combination of individual group therapies consisting of 
physical exercises aimed at strengthening muscles in combination with massage treatments and swimming. It is necessary to be careful in connection with massages, as they are part of many Eastern meditations, which can be counterproductive for the human body (eg the death of the son of actress Edita Grúberová as a result of holotropic breathing). Many people reach for transcendental meditation in order to break free from the pitfalls of the modern world, as they are tired of everyday life and seek the potential way of liberation in relaxation techniques. The desired effect does not always occur. These techniques with the spiritual background of the elements of Eastern religions (Hinduism, Buddhism) can indeed pose a fatal risk to people. (Hebblethwaite, 1997).

Health as a lifestyle, physical and spiritual value. An integral part of wellness is relaxing music. At present, there is a new trend of consumption of culinary specialties together with undergoing spa treatments, the so-called wellness gastronomy. Wellness gastronomy is related to relaxation, fitness and a healthy lifestyle to some extent. For its existence, it needs a wellness hotel, in which guests have at their disposal a wide repertoire of services from the consumption of elements of healthy cuisine, wholemeal bread, fresh vegetables, fruits and legumes. (Borsányiová, 2012) Wellness gastronomy as a new trend in gastronomy and tourism is generally very popular with those interested in mating culture.

Health as a value has religious significance, as it is an important rule of human life in monotheistic religions, especially in the Christian understanding of Ten Commandments. Specifically, it is the commandment Thou Shalt Not Kill, which declares that one should protect one's health at all costs. Any deliberate damage to health is a serious misdeed (eg inappropriate clothing, drunkenness, drugs, etc.) In certain cases, a disease that occurs in a human being is considered a punishment for transgressions that he must endure in order to reach God's perfection. We have already encountered this situation in Ancient Egypt. The ancient Egyptians believed in righteous striking down with a disease as the man in question sinned. Only a god can deliver a sick person from disease (Zaviš, 2012) In this aspect lies the mastery of the healing process.

Health has a dichotomous significance, it can be an innate genetic predisposition given by the subsequent longevity of human life, but on the other hand also by proper eating habits, hygiene and sports (walking, strengthening and swimming). The main peak of health is in youth, or early adulthood, in middle age we observe a gradual loss of physical strength (muscle thinning, weakening of vital functions, etc.) At present, there is an increase in the number of extended educational programs on health protection, e.g. National health promotion programs, the main purpose of which is the long-term improvement of the health status of the population of the Slovak Republic, the extension of life expectancy and the increase of the quality of life. (Aktualizácia NPPZ, 2014) In terms of content, they promote a healthy lifestyle by way of consuming healthy foods (apple against indigestion, garlic and lemon lower blood pressure, broccoli contains anti-cancer substances). Cooked foods (aspic - bones, chicken broth - against colds, rabbit meat-stomach problems) and dairy products (yoghurts, cheeses, milk - digestive problems, fiber and intestinal flora) have a positive effect on the human body. The key prevention is to avoid stressful situations, unhealthy foods (fried, sweet), smoke-filled areas and a high-energy drinks that burden the liver. Excessive consumption of highly concentrated fruit juices is also dangerous. The key to the desired success is a proper lifestyle.

In history specific attention has also been paid to the beauty of the human body. Natural dyes for women were already known to the ancient Egyptians. Henna hair products, face masks and treatments are generally known. Red-brown henna from a henna tree leaf was used to color nails, palms and soles. The ancient Egyptians used a cleansing cream of oil, lime, and perfumes of flowers, seeds, and fruits instead of soap. They also liked fragrant oils, which they applied to the surface of the skin as a protective element against the harsh sun. (Binghamová a kol., 2004) Compared to preservatives, they did not burden the human body to the same extent as today's ones 
with a large amount of antioxidants or antiperspirants. Natural preparations are more advantageous from the ecological point of view. The issue of hygiene has always received a great deal of attention from the point of view of society.

Conclusion. Health is the basis of human existence, which is to some extent related to collectivity, as it is a vital phenomenon that we cannot do without. "Being healthy is important not only for the person himself, but also for society." (Eliašová, 2009, p. 169) It is a vital philosophy that also emphasizes individual care for the cleanliness of clothing, a favorable look and clean skin without plaques. Health is a category of ritual significance, as it is a valuable, even sacred phenomenon with a corresponding axiological function.

\section{References}

Aktualizácia NPPZ (2014), "Preambula, Úrad verejného zdravotníctva SR", Bratislava, 32 p., viewed 23 December 2020, available at: https://www.uvzsr.sk/docs/info/podpora/vlastny_material_ NPPZ_2014.pdf

Binghamová, J. a kol. (2004), Encyklopedie starověkého světa s odkazy na internet (Preklad Monika Vosková), Perfekt, a. s., Bratislava, 400 p.

Borsányiová, D.(2012), "Wellness gastronómia - top trend v súčasnosti", viewed 23 December 2020, available at: https://gastrooo.estranky.sk/clanky/wellness-gastro/

Děd, M.(2016), "Hodnoty a ich klasifikácia: Values and classification", Revue spoločenských a humanitných vied [elektronický dokument], Vysoká škola Danubius, Sládkovičovo, Vol. 4, No. 1-2, (2016), pp. 1-11.

Eliašová, D. (2009), Slovenské kúpel'níctvo v 20. storočí, Vydavatel'stvo Ekonóm, Bratislava, 202 p.

Farkašová, E.(2004), "Filozofia: radkyňa, vychovávatel'ka, sprevádzatel'ka životom ?", pp. 233238, Andreanský, E.(Ed.). Filozofia a život - Život filozofie. Zborník príspevkov z vedeckej konferencie s medzinárodnou účast'ou konanej v rámci 6. výročného stretnutia SFZ v dňoch 16.-18. septembra 2004 v Prešove, Slovenské filozofické združenie pri SAV a Katedra filozofie FF PU v Prešove, Iris, Prešov, $466 \mathrm{p}$.

Hebblethwaite, B. (1997), Ethics and Religion in a Pluralistic Age, T\&T CLARK, Edinburgh, 216 p. Mrkvová, K. (2016), "Historický vývoj kúpel'níctva a wellness", pp. 19-24, Strážovská, H. (Ed.). Ekonomika cestovného ruchu a podnikanie: vedecký časopis Obchodnej fakulty Ekonomickej univerzity v Bratislave, Katedra služieb a cestovného ruchu OBF EU, Bratislava, Vol. 8, No. $1(29) / 2016,70 \mathrm{p}$.

Oborný, J. (2015), Filozofia a šport, Univerzita Komenského v Bratislave, Bratislava, 158 p.

Piaček, J.(2002), "Synkriticizmus ako filozofia a spôsob života", Filozofia, Filozofický ústav SAV, Bratislava, Vol. 57, No. 7, pp. 475-492.

Rybář, R.(2010), "Filozofie zdraví ako výchova ke zdravému životu", pp. 13-20, Řehulka, E.(Ed.). Škola a zdraví pro 21. století. Príspěvky k výchově ke zdraví, Masarykova univerzita v Brne, Brno, $390 \mathrm{p}$.

Zaviš, M. (2012), Staroveký svet zdravia a choroby, Univerzita Komenského v Bratislave, Bratislava, $206 p$.

\section{(C) Emanuel Orban}

